Sains Malaysiana 50(12)(2021): 3505-3522

http://doi.org/10.17576/jsm-2021-5012-04

\title{
The Provenance and Tectonic Settings of the Greywacke Member of the Late Neoproterozoic Hazara Formation Lesser Himalayas, Northern Pakistan: Evidence from Geochemistry and Petrography
}

(Penentuan dan Tektonik Ahli Grewake Provenans Formasi Hazara Neoproterozoik Akhir Himalaya, Utara Pakistan: Bukti daripada Geokimia dan Petrografi)

\section{Qamar Uz Zaman Dar, Pu Renhai*, Zulqarnain Sajid, Mubashir Mehmood, Abdul Wahab, Muhammad JEHANGIR KHAN \& TAJJAMAL LATIF}

\begin{abstract}
The petrographic and geochemical analysis of the greywacke horizon of the late Neoproterozoic Hazara Formation from the Hazara Mountains has been investigated to determine the provenance, tectonic settings and weathering history of the sediments. The Late Neoproterozoic Hazara Formation is a thick sedimentary sequence comprising of greywacke, shale, argillites, siltstone, and limestone. The greywackes are characterized by fine to medium-grained, moderately sorted and sub-angular to sub-rounded framework grains. They are rich in quartz, lithic fragments and clay minerals. The petrographic investigation of the greywackes categorized them as feldspathic greywacke in the QFR diagram. The quartz content is higher in sandstone and may reach to $70 \%$, which indicates a weathered felsic source. Chemical Index of Alteration values of greywacke suggests that the source region has experienced highly weathering conditions with a warm and moist climate. Various geochemical interpretations, elemental ratios like Th/Sc, La/Sc,Th/Cr, and positive Eu anomalies indicate that the greywackes of the Hazara formation derived from a felsic source and were deposited within an active continental margin tectonic settings. The main source area of the sediments of the greywackes was located to south to southeast, which may possibly be the Aravali orogeny, central Indian craton and Bundelkhand craton. Finally, the geochemical data of the major elements point to a felsic igneous provenance for the greywacke.
\end{abstract}

Keywords: Geochemistry; greywacke; Hazara Formation; late neoproterozoic; petrography

ABSTRAK

Analisis petrografi dan geokimia ufuk greiwake Formasi Hazara Neoproterozoik akhir dari Pergunungan Hazara telah dikaji untuk menentukan provenans, tetapan tektonik dan sejarah luluhawa sedimen. Formasi Hazara neoproterozoik akhir adalah urutan sedimen tebal yang terdiri daripada grewake, serpih, argilit, batu karang dan batu kapur. Grewake dicirikan oleh butiran kerangka halus hingga sederhana, tersusun dengan sederhana dan subsudut hingga subbulat. Ia kaya dengan kuarza, serpihan litik dan mineral tanah liat. Penyelidikan petrografi grewake mengkategorikannya sebagai grewake felspar dalam rajah QFR. Kandungan kuarza lebih tinggi dalam batu pasir dan mungkin mencapai 70\%, yang menunjukkan sumber felsik lapuk. Indeks kimia perubahan nilai grewake menunjukkan bahawa wilayah sumbernya mengalami keadaan cuaca yang sangat panas dan lembap. Pelbagai tafsiran geokimia, nisbah unsur seperti $\mathrm{Th} / \mathrm{Sc}, \mathrm{La} / \mathrm{Sc}, \mathrm{Th} / \mathrm{Cr}$ dan anomali Eu positif menunjukkan bahawa grewake pembentukan Hazara berasal daripada sumber felsik dan disimpan dalam tetapan tektonik margin benua aktif. Kawasan sumber utama sedimen grewake terletak di selatan ke tenggara, yang mungkin merupakan orogenesis Aravali, kraton India tengah dan kraton Bundelkhand. Akhirnya, data geokimia unsur-unsur utama menunjuk ke arah asal igneus felsik untuk grewake.

Kata kunci: Geokimia; grewake; pembentukan Hazara; neoproterozoik lewat; petrografi

\section{INTRODUCTION}

The late Neoproterozoic Hazara Formation is a thick Sedimentary succession widely exposed in Hazara and Kashmir regions of northern Pakistan. The geochemical features of the clastic sedimentary rocks are usually regulated by the source rock composition, physical and chemical weathering, sediment transport, and post- 
depositional diagenetic processes (McLennan et al. 1993). Provenance, tectonic setting, orogenic processes, paleoclimatic reconstruction is commonly carried out through the investigation of clastic sedimentary rocks (Basu 1985). The clastic sedimentary rocks provide significant traces of source rocks undergone from weathering and erosion throughout the geological time (Wang et al. 2013). Clastic sedimentary rocks can be affected by chemical weathering, features of source rock, sorting of sediments, sedimentation processes and post-depositional diagenetic process, subsequently, these processes also affect the chemical history of the rocks (Nesbitt \& Young 1996).

Immobile elements such as $\mathrm{Ce}, \mathrm{Nd}, \mathrm{Y}, \mathrm{La}, \mathrm{Zr}$, $\mathrm{Hf}, \mathrm{Nb}, \mathrm{Sc}$, and $\mathrm{Ti}$ are mostly used for provenance and tectonic setting investigations as they have comparatively low mobility and low residence time in the seawater throughout the sedimentary process (Holland 1978). The petrographic composition of the original sediments of the Hazara Formation has been modified by later processes such as metamorphism and deformation, so the re-establishment of tectonic settings is a difficult task. In this case, geochemistry of major and minor elements can be useful (Bhatia 1983; Roser \& Korsch 1988, 1986). This research is based on the petrographic details and geochemistry of the late Neoproterozoic greywacke of the Hazara Formation. In the previous literature, the researchers such as Butt (1972), Marks and Ali (1961), Middlemiss (1896), Qasim et al. (2018), Umar et al. (2015), Wadia (1931) and Wynne (1878) regarded this unit as sandstone. In this study, the sandstone unit of Hazara Formation is considered as greywacke based on the petrographic and geochemical analysis. The research involved comprehensive fieldwork for mapping the greywacke, detailed petrography for mineralogical composition, geochemistry of the greywacke Horizon of the Hazara Formation. Based on petrographic and geochemical, data discrimination plots are used to infer the tectonic settings of the greywacke. In this study, field observations, petrographic characteristics, and geochemical characteristics are integrated to understand the provenance and tectonic settings of the greywacke of the Hazara Formation. We have investigated the mineralogy major and trace element ratio, including REEs in the greywacke of the Late-Neoproterozoic Hazara Formation. To the best of our knowledge, this is the first comprehensive work on the greywacke of the Late-Neoproterozoic Hazara Formation in the area.

\section{GEOLOGICAL SETTINGS}

Tectonic histories, stratigraphic studies, and depositional system holds significant information about the basin evolution (As-Saruri et al. 2010). Lithology from the late Proterozoic to Holocene are exposed in the Hazara Basin (HB) within lesser Himalaya north Pakistan. The Hazara area is considered to be a geologically important province due to stratigraphic, sedimentological, and structural relations caused by the Himalayan orogeny, as well as containing useful economic minerals (Shah \& Moon 2004).

The study area is situated in the HazaraFold and Thrust belt in the Lesser Himalayas, Northern Pakistan. The Hazara trough is constrained on the southern side by the Main Boundary thrust (MBT) and in the northern side by the Panjal thrust. At the same time, the Islamabad Peshawar road is dividing the Hazara trough in the east from the Kala Chitta Range in the west. The main structural elements of the area are Hazara Kashmir Syntaxis (HKS); Main Mantle thrust (MMT), Main Karakorum thrust (MKT), MBT, Hazara Thrust, and Punjal Thrust (Figure 1).

The HKS marks the borderline among central and western Himalayas (Bossart et al. 1988). Nathiagali Thrust is a marginal line that differentiates hinterland from the foreland. It continues westward as Hissartang fault in the Hazara Galiat area and outer margin of Attock Cherat Range (Yeats \& Hussain 1987). The MMT is a zone that lay off the Tethyan Himalayas towards the south and juxtaposes it with the Indian plate (Tahirkheli 1979). MKT divides the deformed igneous and metasedimentary rocks of the Karakoram block in the north, from the Kohistan Island Arc complex in the south. The MMT is a suture zone of the Himalayan territory, and it clips Kohistan Island Arc (KIA) with the Indian and Asian plates in the north and south separately (Tahirkheli 1979). The MBT is an about $2500 \mathrm{~km}$ long mega shear zone of the Himalayan area, juxtaposing Precambrian to Cenozoic rocks in the north over the younger sequence (if saying the age before than it should be said here as well) to the south (Seeber et al. 1981).

Hazara mountainous region is an example of the active tectonic fold belt and shows significant evidence of the active ongoing tectonic activities due to the IndoPakistan plate movement. The stratigraphic successions exposed in the investigated area range from Precambrian to recent (Table 1). The Precambrian stratigraphic sequences form the basement, while the Cambrian to recent sequences form the cover (Qasim et al. 2018). The Hazara Formation comprises of greywacke sandstone, shale, slate, siltstone, mudstone, and limestone units (Butt 1972). The formation occupies an extensive area of Hazara and Kashmir region with a thickness of $2400 \mathrm{~m}$ (Figure 2). The greywacke and siltstone show a variety of well-preserved sedimentary features such as ball and 
pillow structures, ripple marks, mud creak, slumps, and cross-stratification. In the investigated area, the base of the Hazara Formation is not exposed. The base of the sequence is covered with recent deposits while the upper part of the Hazara Formation is trusted over the Eocene rocks by the Nathiagali Thrust (Figure 3). The stratigraphic sequence exposed in the Hazara area is given in Table 1.

Hazara Formation is present within the Hazara Basin (HB) which is geologically confined between Panjal Fault in north and MBT in south, lies in the east and northeast of Kalachitta Block. It geographically covers the area of Galiat-Abbottabad in north and Margalla hills in south. $\mathrm{HB}$ is comprised of E-W trending sedimentary belt which converges into western limb of HKS in east and northeast and truncated by Indus River and Kalachitta Range in west and southwest, respectively. HB is represented by a thick sedimentary sequence (Figure 2) of northern edge of Indian Plate ranging in age from Pre Cambrian to Eocene. There are numerous thrust faults and Normal faults that cut the folded sedimentary sequence (Dar et al. 2021).

The paleogeographic position of the HB have been explained in term of the three tectonic phases. The first Himalayan phase includes the over thrusting of the Precambrian Salkhala units over the Late PaleozoicMesozoic units. The compression caused by this thrust also affected the Murree realm, causing the PaleoceneEocene Murree shales and the upper Precambrian to Cambrian Hazara Formation to fold into an open fold called the Muzaffarabad anticline. The timing of the dome development is not completely certain, but a correlation of the dome in the Hazara-Kashmir Syntaxis with the Nanga Parbat Syntaxis, which is an uplift structure, seems likely. A tectonic cooling fission track age near the apex of the Hazara-Kashmir Syntaxis which is dated at 16 my (Zeitler 1985) suggests an updoming in the early Miocene. The transport direction of all these events was southwest wards. Consequently (second phase) a progressive change of over thrust direction leading to a final southeast wards transport direction developed a sinistral ductile shear zone in the already formed chain. This shear zone is a feature of large tectonic scale, induced by differential movement of crustal blocks; it separates the Lesser Himalaya from the Higher Himalaya (Greco et al. 1989). The strain arising from a narrowing down of this shear zone during its development led to the production of the mylonites west of Balakot. The final third phase results in a southsoutheast ward thrust movement, recorded in the western area of the Syntaxis; this mass transport is responsible for the superimposed folding in the Muzaffarabad area as well as the formation of a crenulation cleavage in the higher thrust units. In conclusion, a counter clockwise turning of overthrust shear direction from NE-SW to NNW-SSE seems to best accord for the structural and geometric data we have witnessed and for the formation

of the study area.

TABLE 1. Stratigraphic Successions of the Hazara area after Latif 1970

\begin{tabular}{lcc}
\hline Formation & Lithology & Age \\
\hline Murree Formation & Sandstone, siltstone and claystone & Miocene \\
Kuldana Formation & Shale, gypsum with interbeds of limestone & Eocene \\
Chorgali Formation & Limestone with interlayers of shale & Eocene \\
Margala Hill Limestone & Nodular limestone with interbedded shale, marl & Eocene \\
Patala Formation & Marly shale with limestone beds & Paleocene \\
Lockhart Limestone & Nodular limestone with occasional marl, shale layers & Paleocene \\
& $\ldots \ldots . .$. Unconformity........... & Cretaceous \\
Kawagarh Formation & Sandy limestone, shale interbeds & Cretaceous \\
Lumshiwal Formation & Sandstone, siltstone, shale interlayers & Cretaceous \\
Chichali Formation & Glauconitic sandstone, shale & Jurassic \\
Samana Suk Formation & $\ldots . . . .$. Unconformity........... & Jurassic \\
Datta Formation & Limestone with intra-formational conglomerates & Cambrian
\end{tabular}




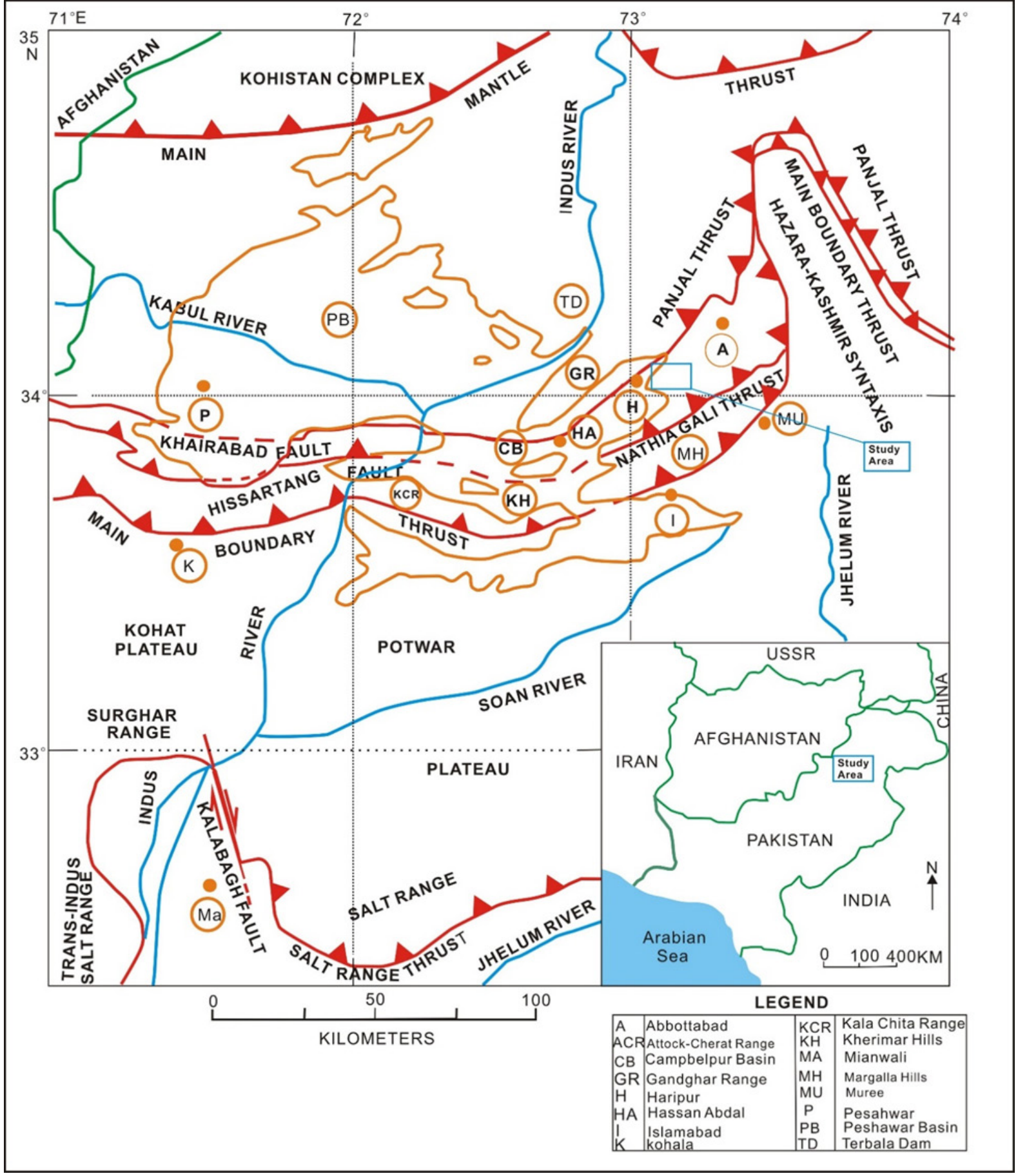

FIGURE 1. Tectonic map of Northern Pakistan showing major structural boundaries modified after Hylland (1990) and Dar et al. (2021)

Hazara Formation Greywacke, shale, siltstone, the Hazara ${ }_{1}$ Mountains that included sample SAMPLING AND ANALYTICAL METHODS observations of lithological variations, and investigation of A comprehensive field investigation was carried out in various sedimentary features. The field work was carried out along the Lora Maqsood road. The sampling for this 

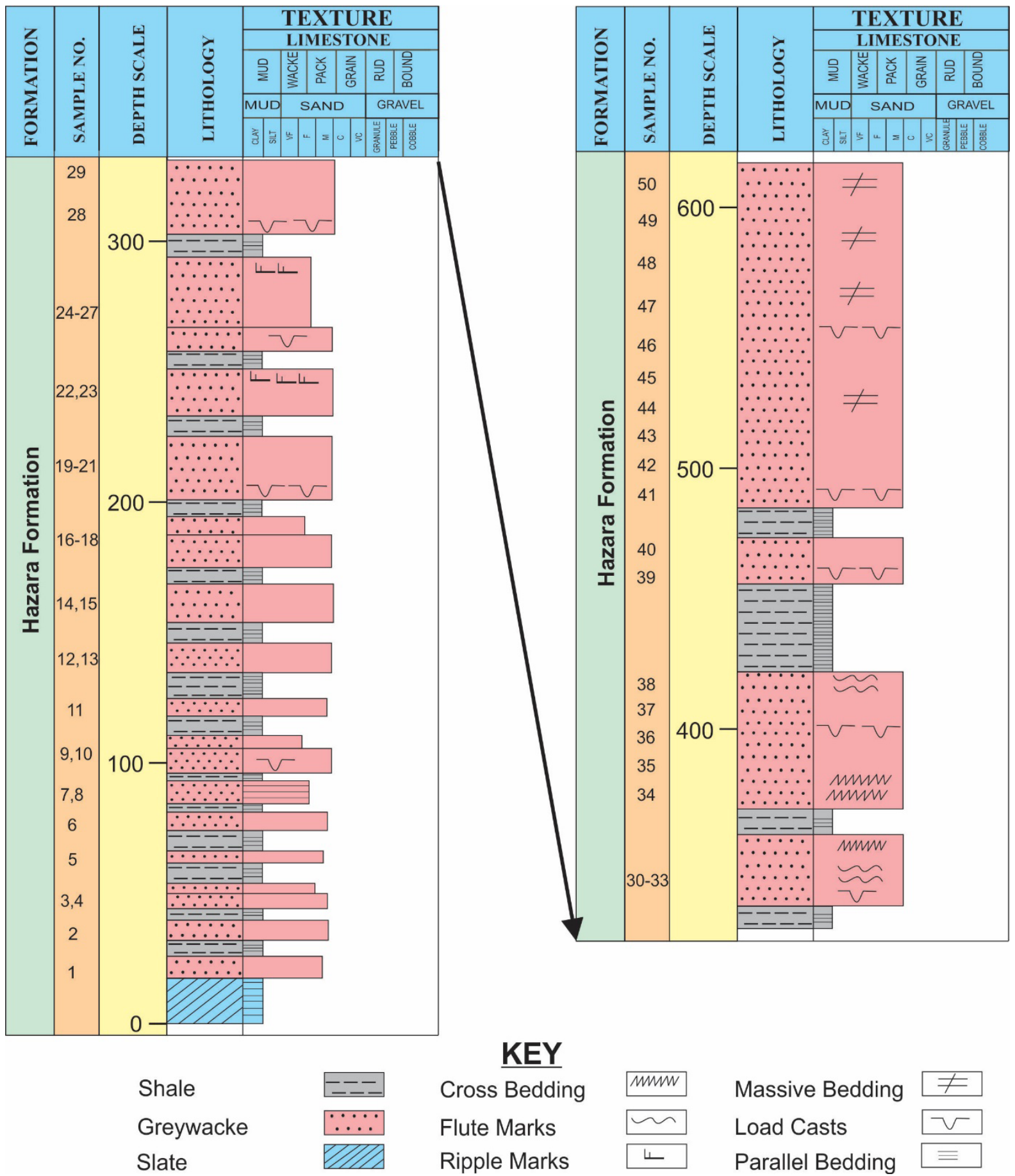

FIGURE 2. Representative sedimentary log of the Hazara Formation

study was mainly focussed on the greywacke. Fifty fresh representative greywacke samples of the Hazara Formation were collected from well-exposed outcrops. Fractured and Weathered outcrops were avoided. The collected samples were cleaned and washed. Selected samples were cut down into slices and attached on glass slides then polished to gain the required thickness. Polished thin sections of selected samples were analysed for mineralogical 

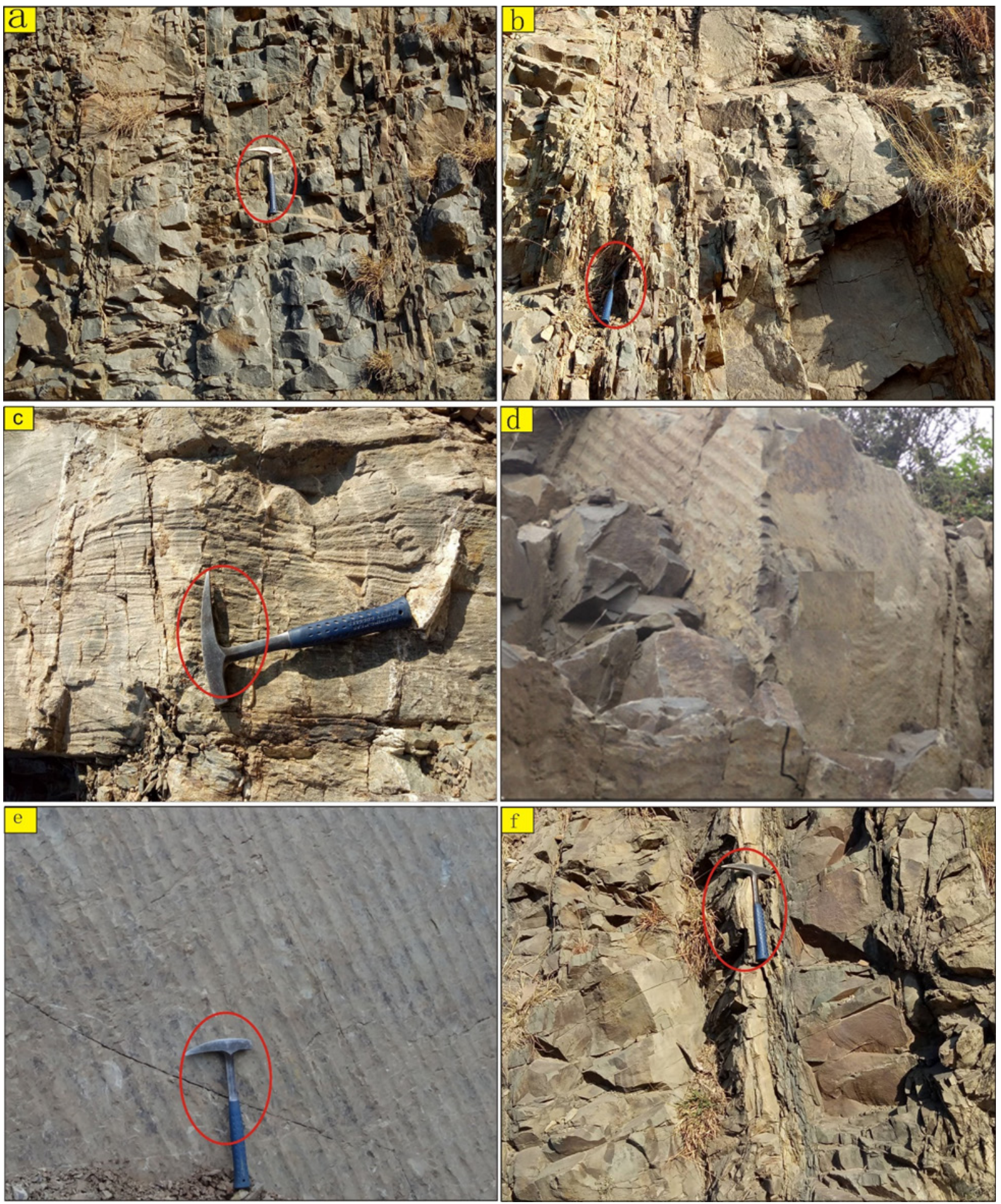

FIGURE 3. Field photographs of greywacke member of Hazara Formation (a) thin-bedded greywacke (b) thin-bedded greywacke and thick-bedded greywacke (c) cross stratified greywacke (d) thin-bedded greywacke (e) Ripple marks (f) greywacke with shale intercalations

composition using petrographic microscope. Thirty samples were designated for major and trace element analysis. The selected samples were crushed into powder for X-ray fluorescence (XRF) analysis. Major elements 
concentration in greywacke is measured by using standard XRF technique at the State Key Laboratory of continental dynamics Northwest University. The concentration of the trace elements, including REE, was conducted by inductively coupled plasma mass spectrometry (ICP-MS) technique. The results of the trace elements were revised for instrumental error. Analytical accuracy for trace elements is better than 5\%. In these study (Herron 1988; Pettijohn et al. 1972), classification scheme and the discrimination diagrams of Bhatia (1983) and Roser and Korsch (1986) were used to deduce the provenance and tectonic settings of the greywacke of the Hazara Formation.

\section{RESULTS}

\section{PETROGRAPHIC CHARACTERISTICS}

The greywacke of the Hazara Formation is fine to mediumgrained, exhibiting a variable scale of bedding thin to massive. The greywacke is poorly sorted and dominantly composed of quartz, feldspar with a subordinate amount of lithic fragments (Figure 4). To examine the model composition of greywacke of the Hazara Formation, thin sections were point counted to around 300 points, and explanation for diverse grains types is determined as in Dickinson (1985). The point count data shows that the framework constituents are quartz, feldspar, lithic fragments and heavy minerals. Quartz is dominant in the greywacke framework grains; sub angular to angular shape, mostly comprises of monocrystalline type. Whereas, the quartz grains with polycrystalline and undulatory extinction are rare (Figure 4). Detrital heavy minerals in the greywacke of Hazara Foramtion are mostly tourmaline. Few of the quartz grains display embayed borders demonstrating the limited disbanding of quartz grains during compaction and diagenesis. Quartz veins can be observed at the outcrops of greywacke and also under the thin section.
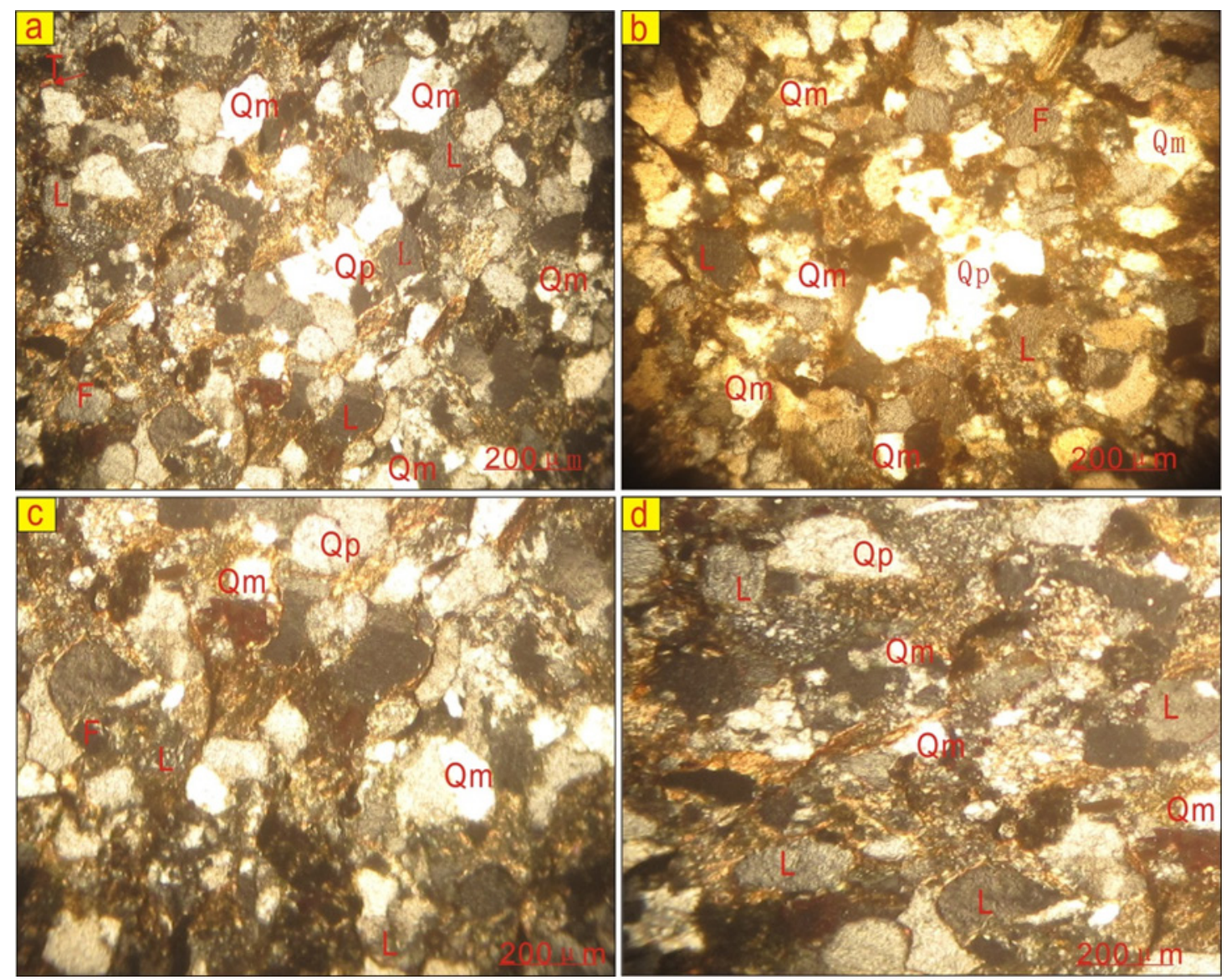

FIGURE 4. Photomicrographs of the greywacke of the Hazara Formation showing major framework grains (a) framework grains $\mathrm{Q}=$ quartz, $\mathrm{Qm}=$ monocrystalline quartz, $\mathrm{Qp}=$ polycrystalline quartz, $\mathrm{L}=$ lithic fragments, $\mathrm{T}=$ Tourmaline, (b) fine to medium-grained sandstone depicting overall quartz-rich mineralogy, (C) f = feldspar and other framework grains (d) lithic fragments rich sandstone 


\section{GEOCHEMISTRY \\ MAJOR ELEMENTS}

The major and trace elemental composition of the analysed samples is given in Table 2. All the investigated samples show a high concentration of $\mathrm{SiO}_{2}$, fluctuating between 60 and $76.05 \%$. The $\mathrm{Al}_{2} \mathrm{O}_{3}, \mathrm{CaO}$, and $\mathrm{Fe}_{2} \mathrm{O}_{3}$ are relatively high from 2.55 to $22.36 \%$. The concentrations of $\mathrm{TiO}_{2}, \mathrm{MnO}, \mathrm{MgO}, \mathrm{K}_{2} \mathrm{O}$ and $\mathrm{P}_{2} \mathrm{O}_{5}$ are low, ranging from $\mathrm{TiO}_{2}$ is 0.13 to $0.80 \%, \mathrm{MnO}$ is 0.004 to $0.17 \%, \mathrm{MgO}$ is 0.17 to $3.27 \% \mathrm{~K}_{2} \mathrm{O}$ is 0.95 to $4.42 \%$, and $\mathrm{P}_{2} \mathrm{O}_{5}$ is ranging from 0.053 to $0.21 \%$. The major elemental composition of sedimentary rocks is commonly regulated through clay minerals and non-clay silicate periods (Cox et al. 1995). Major elements and trace element data is used to classify the greywacke by binary plots (Herron 1988; Pettijohn et al. 1987). A variation diagram of $\mathrm{SiO}_{2} / \mathrm{Al}_{2} \mathrm{O}_{3}$ versus $\mathrm{K}_{2} \mathrm{O} /$
$\mathrm{Na}_{2} \mathrm{O}$ after (Wimmenauer 1984) demonstrates that most of the sample falls into the greywacke field (Figure 5(a)). The $\log \left(\mathrm{Na}_{2} \mathrm{O} / \mathrm{K}_{2} \mathrm{O}\right)$ versus $\log \left(\mathrm{SiO}_{2} / \mathrm{Al}_{2} \mathrm{O}_{3}\right)$ diagram (Pettijohn et al. 1972), indicates that most of the samples plot in the greywacke field and 2 plot into litharenite field (Figure 5(b)). The variation diagram from Herron (1988) is the binary plot of $\log \left(\mathrm{Fe}_{2} \mathrm{O}_{3} / \mathrm{K}_{2} \mathrm{O}\right)$ versus $\log \left(\mathrm{SiO}_{2} / \mathrm{Al}_{2} \mathrm{O}_{3}\right)$ demonstrates that most of the samples plot in the wacke field (Figure 5(c)). The classification of the greywacke of the Hazara Formation modified after Herron (1988), Marston (1978), Pettijohn et al. (1972) and Roser and Korsch (1986) is given in Figure 5(a) - 5(d). The major element composition of the analysed greywacke is comparatively enriched in $\mathrm{Al}_{2} \mathrm{O}_{3}$, however, $\mathrm{Fe}_{2} \mathrm{O}_{3}$ and $\mathrm{MgO}$ and $\mathrm{K}_{2} \mathrm{O}$ and $\mathrm{Na}_{2} \mathrm{O}$ values are depleted which indicates the presence of clay minerals in the greywacke (Herron 1988).

TABLE 2. Chemical composition of the greywacke member of the Hazara Formation

\begin{tabular}{|c|c|c|c|c|c|c|c|c|c|c|}
\hline Element & SS1 & $\mathrm{SS} 2$ & $\mathrm{SS} 3$ & SS4 & SS5 & SS6 & SS7 & SS8 & SS9 & SS10 \\
\hline $\mathrm{SiO}_{2}(\mathrm{wt} \%)$ & 76.62 & 72.04 & 70.05 & 75.02 & 69.05 & 71.11 & 68.55 & 70.12 & 72.4 & 70.19 \\
\hline $\mathrm{Al}_{2} \mathrm{O}_{3}$ & 15.65 & 14.9 & 15.33 & 16.61 & 16.86 & 14.64 & 13.9 & 16.51 & 17.08 & 15.7 \\
\hline $\mathrm{Na}_{2} \mathrm{O}$ & 2.25 & 3.01 & 1.55 & 2.22 & 2.55 & 3.33 & 2.15 & 1.9 & 2.8 & 2.14 \\
\hline $\mathrm{P}_{2} \mathrm{O}_{5}$ & 0.1 & 0.02 & 0.08 & 0.05 & 0.1 & 0.15 & 0.13 & 0.15 & 0.19 & 0.1 \\
\hline $\mathrm{MgO}$ & 0.08 & 0.02 & 0.09 & 0.03 & 0.08 & 0.08 & 0.06 & 0.04 & 0.07 & 0.09 \\
\hline $\mathrm{Fe}_{2} \mathrm{O}_{3}$ & 2.57 & 2.49 & 1.9 & 2.5 & 1.88 & 2.1 & 1.95 & 2.33 & 2.65 & 2.4 \\
\hline $\mathrm{CaO}$ & 0.53 & 0.59 & 0.43 & 0.55 & 0.48 & 0.61 & 0.33 & 0.51 & 0.45 & 0.53 \\
\hline $\mathrm{TiO}_{\square}$ & 0.54 & 0.61 & 0.49 & 0.61 & 0.55 & 0.67 & 0.55 & 0.45 & 0.51 & 0.66 \\
\hline $\mathrm{K}_{2} \mathrm{O}$ & 3.02 & 1.9 & 2.08 & 2.65 & 3.33 & 1.33 & 2.33 & 3.12 & 1.75 & 1.45 \\
\hline PIA & 76.6 & 73.9 & 81 & 79.13 & 78.2 & 74.3 & 79.1 & 81.11 & 77.5 & 79.3 \\
\hline CIW & 84.9 & 80.5 & 88.5 & 85.7 & 84.7 & 78.79 & 89.3 & 87.5 & 83.76 & 85.46 \\
\hline ICV & 0.51 & 0.57 & 0.39 & 0.45 & 0.43 & 0.54 & 0.51 & 0.41 & 0.48 & 0.46 \\
\hline CIA & 76.6 & 73.33 & 81.97 & 79.13 & 78.27 & 74.34 & 75.58 & 81.09 & 77.53 & 79.49 \\
\hline Li (ppm) & 46.31 & 45.32 & 40.51 & 45.98 & 39.55 & 41.54 & 45.66 & 41.33 & 47.67 & 40.97 \\
\hline $\mathrm{Be}$ & 12.7 & 13.65 & 10.98 & 11.76 & 18.98 & 15.76 & 12.56 & 16.12 & 12.87 & 14.76 \\
\hline $\mathrm{Sc}$ & 17.21 & 19.21 & 14.54 & 13.15 & 17.15 & 18.56 & 13.65 & 18.87 & 19.12 & 15.13 \\
\hline $\mathrm{Cr}$ & 134.3 & 140.81 & 156.78 & 156.56 & 144.86 & 130.66 & 133.98 & 141.12 & 138.12 & 135.5 \\
\hline Co & 21.61 & 22.54 & 23.16 & 20.12 & 24.52 & 21.14 & 26.16 & 25.19 & 20.98 & 22.17 \\
\hline $\mathrm{Ni}$ & 57.01 & 58.09 & 60.12 & 59.17 & 61.32 & 62.12 & 57.12 & 56.75 & 62.76 & 59.55 \\
\hline $\mathrm{Cu}$ & 41.51 & 40.43 & 43.12 & 38.99 & 43.43 & 40.77 & 43.43 & 39.76 & 42.11 & 39.54 \\
\hline $\mathrm{Zn}$ & 77.19 & 79.12 & 74.66 & 73.98 & 80.14 & 75.14 & 73.87 & 75.76 & 74.1 & 70.45 \\
\hline
\end{tabular}




\begin{tabular}{lcccccccccc}
$\mathrm{Ga}$ & 8.63 & 7.86 & 10.09 & 9.16 & 8.11 & 6.99 & 7.43 & 8.99 & 10.25 & 7.55 \\
$\mathrm{Rb}$ & 168.6 & 165.78 & 159.78 & 163.54 & 170.78 & 167.54 & 162.54 & 165.85 & 169.45 & 16.3 \\
$\mathrm{Sr}$ & 131.14 & 130.13 & 132.14 & 130.29 & 133.23 & 134.18 & 132.98 & 135.12 & 130.12 & 129.6 \\
$\mathrm{Y}$ & 23.5 & 22.4 & 24.12 & 25.56 & 26.12 & 22.43 & 24.18 & 21.67 & 20.54 & 21.87 \\
$\mathrm{Zr}$ & 146.3 & 141.65 & 143.11 & 140.23 & 138.67 & 138.65 & 141.76 & 143.67 & 145.19 & 144.8 \\
$\mathrm{Nb}$ & 18.51 & 17.15 & 19.21 & 16.87 & 19.87 & 20.09 & 15.45 & 14.87 & 18.91 & 17.9 \\
$\mathrm{Sn}$ & 2.56 & 2.48 & 3.01 & 1.98 & 2.11 & 3.01 & 2.76 & 2.5 & 3.12 & 2.87 \\
$\mathrm{Sb}$ & 0.19 & 0.12 & 0.19 & 0.16 & 0.11 & 0.22 & 0.19 & 0.21 & 0.17 & 0.19 \\
$\mathrm{Cs}$ & 7.78 & 7.12 & 6.98 & 8.11 & 7.56 & 8.56 & 6.9 & 5.5 & 8.54 & 7.87 \\
$\mathrm{Ba}$ & 264.5 & 261.52 & 260.12 & 265.12 & 267.12 & 270.21 & 265.49 & 260.28 & 261.19 & 263.2 \\
$\mathrm{~Pb}$ & 2.97 & 2.5 & 2.13 & 1.98 & 3.77 & 4.12 & 2.12 & 1.5 & 2.55 & 2.87 \\
$\mathrm{Th}$ & 7.61 & 7.5 & 8.13 & 6.98 & 5.88 & 7.45 & 6.63 & 5.78 & 8.11 & 6.12 \\
$\mathrm{U}$ & 3.24 & 2.78 & 3.16 & 2.14 & 3.5 & 2.9 & 3.16 & 2.88 & 1.99 & 3.16 \\
$\mathrm{La}$ & 34.45 & 36.13 & 32.77 & 37.41 & 33.12 & 34.87 & 35.11 & 30.54 & 38.11 & 34.12 \\
$\mathrm{Ce}$ & 84.88 & 88.12 & 90.77 & 100.32 & 96.66 & 87.98 & 78.12 & 68.56 & 88.76 & 93.44 \\
$\mathrm{Pr}$ & 7.6 & 7.87 & 9.23 & 10.13 & 8.77 & 7.18 & 9.12 & 8.98 & 6.99 & 7.68 \\
$\mathrm{Nd}$ & 31.32 & 38.76 & 37.17 & 35.51 & 36.96 & 41.44 & 38.61 & 30.46 & 32.14 & 36.81 \\
$\mathrm{Sm}$ & 4.3 & 4.67 & 4.7 & 4.86 & 3.97 & 5.11 & 5.87 & 4.76 & 5.93 & 3.54 \\
$\mathrm{Eu}$ & 0.86 & 1.06 & 1.2 & 1.23 & 0.98 & 1.54 & 1.17 & 0.76 & 1.05 & 1.08 \\
$\mathrm{Gd}$ & 4.33 & 5.11 & 4.54 & 4.7 & 5.08 & 3.98 & 4.11 & 5.11 & 4.76 & 3.95 \\
$\mathrm{~Tb}$ & 0.7 & 0.76 & 0.61 & 0.65 & 0.5 & 0.76 & 0.41 & 0.69 & 0.54 & 0.43 \\
$\mathrm{Dy}$ & 3.45 & 3.51 & 3.48 & 2.98 & 3.85 & 3.21 & 3.78 & 2.9 & 3.65 & 3.72 \\
$\mathrm{Ho}$ & 0.72 & 0.8 & 0.77 & 0.67 & 0.65 & 0.55 & 0.87 & 0.54 & 0.46 & 0.61 \\
$\mathrm{Er}$ & 2.33 & 2.41 & 2.13 & 1.98 & 2.09 & 2.67 & 1.9 & 2.5 & 2.11 & 2.24 \\
$\mathrm{Tm}$ & 0.36 & 0.3 & 0.46 & 0.39 & 0.41 & 0.32 & 0.37 & 0.34 & 0.32 & 0.37 \\
$\mathrm{Yb}$ & 2.18 & 2.77 & 2.46 & 2.33 & 1.9 & 2.08 & 2.66 & 2.13 & 1.97 & 2.54 \\
$\mathrm{Lu}$ & 0.32 & 0.41 & 0.38 & 0.35 & 0.46 & 0.3 & 0.35 & 0.29 & 0.42 & 0.28 \\
\hline & & & & & & & & & & \\
$\mathrm{Ha}$ & & & & & &
\end{tabular}

\section{TRACE ELEMENTS}

The $\mathrm{Zr}$ concentration in Hazara Formation greywacke ranges from 144 to $160 \mathrm{ppm}$, and the average is $152 \mathrm{ppm}$. Sc concentration is 13.15 to $19.11 \mathrm{ppm}$, and the average is 16.37. The concentration of $\mathrm{Cr}$ is ranging from 130 to $156 \mathrm{ppm}$, and the average is $143 \mathrm{ppm}$. The elements $\mathrm{Sr}, \mathrm{Ba}$, and $\mathrm{Rb}$ have an orderly low concentration in the greywacke and are easily mobilized during the process of chemical weathering of the source area (Nesbitt \& Young
1982). Some trace elements like Th, Sc, Co, Zr, and La are immovable during the depositional process and the elements are useful indicators of definite source rocks (Taylor \& McLennan 1985). Trace elements behavior throughout the sedimentary process is complicated due to various reasons like weathering, physical sorting, provenance and post-depositional diagenesis processes (Nesbitt \& Young 1982). 

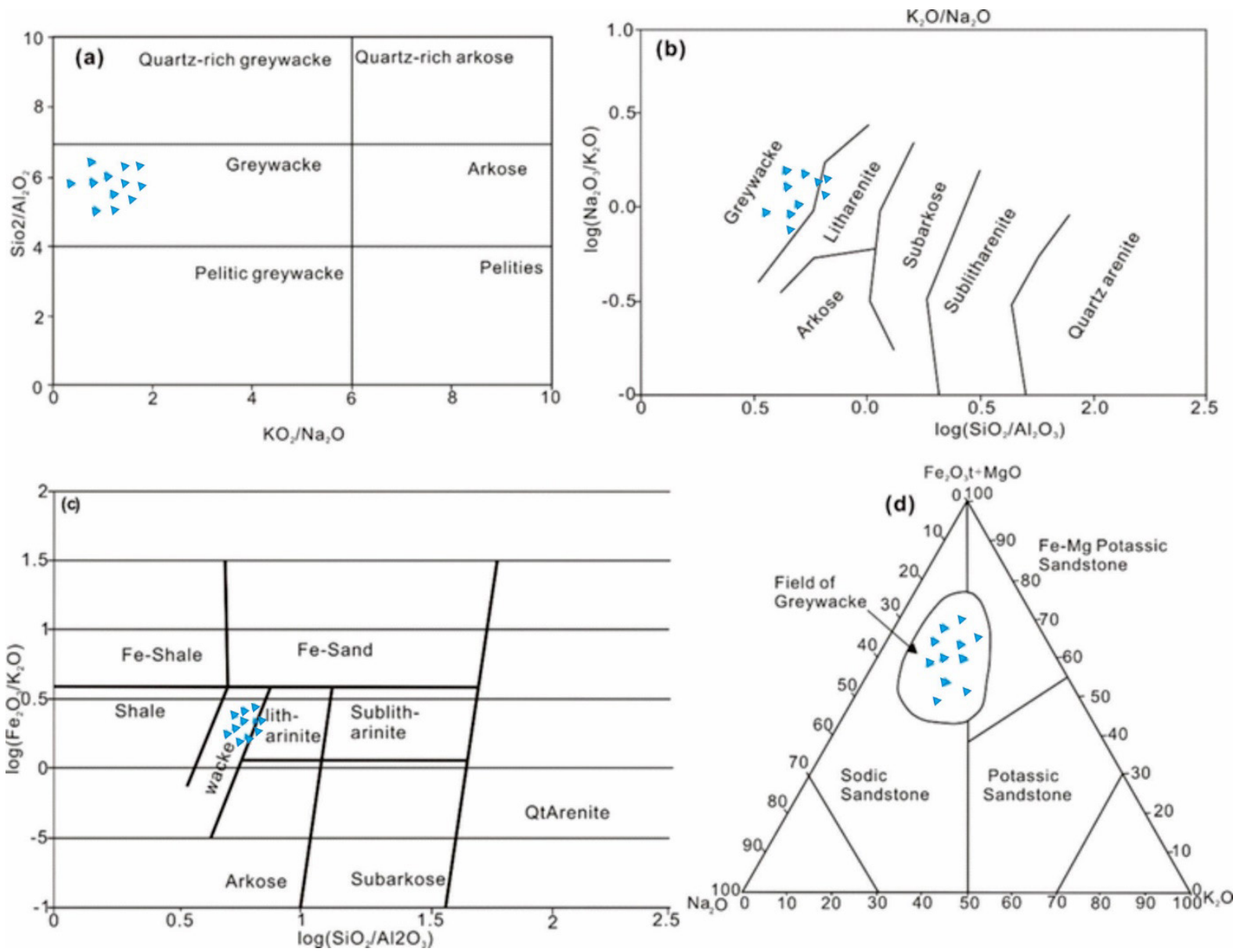

FIGURE 5. Classification of greywacke member of Hazara Formation (a) binary plot of $\mathrm{SiO}_{2} / \mathrm{Al}_{2} \mathrm{O}_{3}$ after Wimmenauer (1984) showing a majority of samples plot in greywacke field (b) Binary plot of $\log \left(\mathrm{Na}_{2} \mathrm{O} / \mathrm{K}_{2} \mathrm{O}\right)$ vs $\log \left(\mathrm{SiO}_{2} / \mathrm{Al}_{2} \mathrm{O}_{3}\right)$ after Pettijohn et al. (1972) emphasizes the greywacke field; (c) binary plot of $\log \left(\mathrm{Fe}_{2} \mathrm{O}_{3} / \mathrm{K}_{2} \mathrm{O}\right.$ against $\log \mathrm{SiO}_{2}$ / $\mathrm{Al}_{2} \mathrm{O}_{3}$ after Herron (1988), after Marston (1978) shows most of the samples fall in the wacke fields; (d) Ternary diagram of $\mathrm{Fe}_{2} \mathrm{O}_{3}{ }^{\mathrm{t}}+\mathrm{Mgo}-\mathrm{Na}_{2} \mathrm{O}-\mathrm{K}_{2} \mathrm{O}$, after Marston (1978) shows most of the samples fall in the greywacke field

\section{REAR EARTH ELEMENTS}

The REEs are mostly immobile and suffer from minor variations during the sedimentary process. The weathering conditions and post-depositional processes like interchange reactions throughout the transportation and deposition are the reasons regulating the REE richness in sedimentary rocks and their richness in source rocks (Bhatia 1983; Cullers 1994). The existence of clay minerals and heavy minerals in the greywacke of the Hazara Formation also leads to the enrichment of REE concentration (Taylor \& McLennan 1985). The europium anomaly has been measured by following (1) (Bau \& Dulski 1996; Dai et al. 2016) as;

$$
\left(\frac{E u_{N}}{E u_{N} *}\right)=\frac{E u_{N}}{\left[\left(S m_{N} \times 0.67\right)+\left(T b_{N} \times 0.33\right)\right]}
$$

Most of the analysed samples of the greywacke has $\mathrm{Eu}$ positive anomaly $(\mathrm{Eu} / \mathrm{Eu}=1.09$ to 1.47$)$ showing the plagioclase richness in the source area, few samples also show negative anomaly values $(\mathrm{Eu} / \mathrm{Eu}=0.2$ to 0.94) suggesting the crystallization of plagioclase 
in the magma of source rock (Taylor \& McLennan 1985). The REE element pattern of the greywacke of the Hazara Formation is normalized with respect to upper continental crust (UCC) values is shown in Figure (6). The samples of Hazara Formation are enriched in REEs in accordance to chondrite REEs.

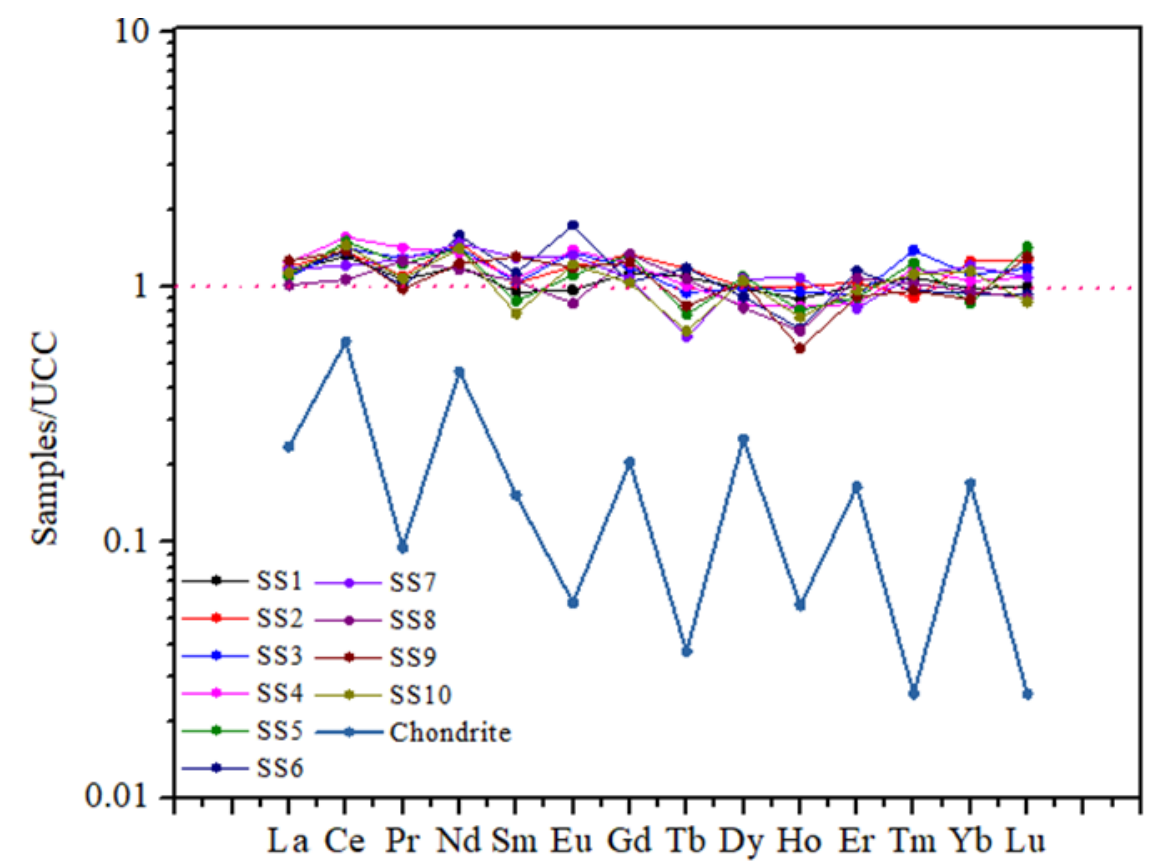

FIGURE 6. Rear earth element pattern of the greywacke member of the Hazara Formation normalized according to UCC values (values from Taylor and McLennan, 1985) and compared with chondrite REEs (values from Sun and McDonough 1989)

\section{DISCUSSION}

\section{SOURCE AREA WEATHERING}

Weathering intensity and characters of the source territory can be quantitatively calculated to compute the Chemical Index of Alteration (CIA) of the resultant clastic sedimentary rocks (Nesbitt \& Young 1984) based on (2)

$$
\mathrm{CIA}=\left[\frac{\mathrm{Al}_{2} \mathrm{O}_{3}}{\left(\mathrm{Al}_{2} \mathrm{O}_{3}+\mathrm{CaO}^{*}+\mathrm{Na}_{2} \mathrm{O}+\mathrm{K}_{2} \mathrm{O}\right)}\right] \times 100
$$

$\mathrm{CaO}^{*}$ is calculated as

$$
\mathrm{CaO}^{*}=\mathrm{CaO}-\mathrm{P}_{2} \mathrm{O}_{5} \times \frac{10}{3}
$$

The Chemical Index of Alteration (CIA) was proposed by Nesbitt and Young (1982). The CIA is based on the principle of increased weathering results richness of $\mathrm{Al}$ at the cost of alkalis and uses the ternary $\mathrm{Plot}_{\mathrm{Al}_{2}} \mathrm{O}_{3}$ $\left(\mathrm{CaO} *+\mathrm{Na}_{2} \mathrm{O}\right)-\mathrm{K}_{2} \mathrm{O}(\mathrm{A}-\mathrm{CN}-\mathrm{K})$ (Figure 7) (Nesbitt \& Young 1984). The CIA values range from 70.33 to 81.91 in the analysed samples. The higher value of CIA reflects a severe weathering and rapid physical erosion of source terrane in active tectonic settings (Nesbitt \& Young 1996). Higher CIA value also indicates weathering in the warm and humid climate, while low CIA values reflect cold or arid conditions (Fedo et al. 1995; Nesbitt \& Young 1982). The gathered CIA values from analysed samples show that the rocks of source terrain are moderate to highly weathered, and the sediments were being transported from the source that has experienced severe physical and chemical weathering in a humid climate.

The petrographic indications, such as the existence of abundant angular grains of plagioclase and K-feldspar grains together with rock fragments, suggest a chemical weathering, quick physical erosion, and deposition in turbidites settings (Absar et al. 2009). The grade of 
chemical weathering can be assessed by computing the plagioclase index of alteration modified from the CIA (Fedo et al. 1995). The weathering history of the igneous rocks and source areas of sedimentary rock can be estimated by using $\mathrm{A}-\mathrm{CN}-\mathrm{K}\left(\mathrm{A}=\mathrm{Al}_{2} \mathrm{O}_{3}, \mathrm{CN}=\mathrm{CaO}+\mathrm{Na}_{2} \mathrm{O}\right.$, $\mathrm{K}=\mathrm{K}_{2} \mathrm{O}$ ) triangular diagram (Figure 7 ) of Nesbitt and Young (1982).

The following equation estimates the plagioclase index of alteration (PIA) values;

$$
\mathrm{PIA}=\left[\frac{\mathrm{Al}_{2} \mathrm{O}_{3}-\mathrm{K}_{2} \mathrm{O}}{\left(\mathrm{Al}_{2} \mathrm{O}_{3}+\mathrm{CaO}^{*}+\mathrm{Na}_{2} \mathrm{O}-\mathrm{K}_{2} \mathrm{O}\right)}\right] \times 100
$$

PIA value is 100 for totally altered material (kaolinite and gibbsite). Weathered plagioclase has a value 50. The analysed samples in over study have PIA value from 74.3 to 81.11 , and the average is 78.03 which suggest that the plagioclase was intensely weathered in the source area. Chemical Index of Weathering (CIW) values show the total sum of chemical weathering experienced by weathered material.

$$
\mathrm{CIW}=\left[\frac{\mathrm{Al}_{2} \mathrm{O}_{3}-\mathrm{K}_{2} \mathrm{O}}{\left(\mathrm{Al}_{2} \mathrm{O}_{3}+\mathrm{CaO}^{*}+\mathrm{Na}_{2} \mathrm{O}\right)}\right] \times 100
$$

The CIW values for the greywacke sandstone range from 78.7 to 89.3 , and the average is 84.91 based on CIW values for the greywacke sandstone. This leads to the interpretation that the rocks were moderate to highly weathered.

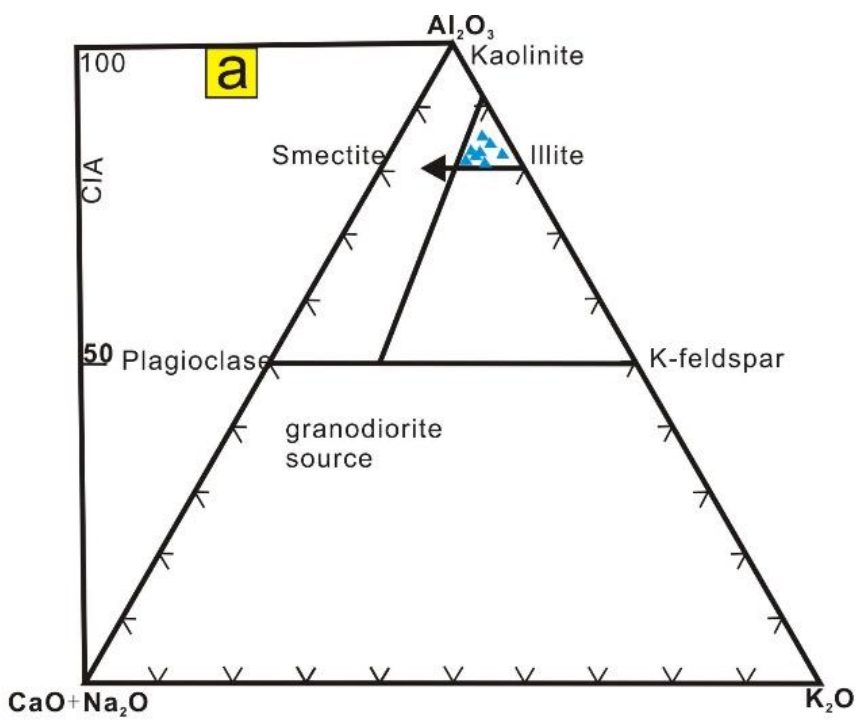

FIGURE 7. A-CN-K ternary diagram of molecular proportions of $\mathrm{Al}_{2} \mathrm{O}_{3}$ $\left(\mathrm{CaO}+-\mathrm{Na}_{2} \mathrm{O}\right)-\mathrm{K}_{2} \mathrm{O}$ for greywackes member of the Hazara Formation with a chemical index of alteration (CIA) scale (CIA values from Cox et al. 1995)

\section{PALEOCLIMATE}

Chemical weathering is the main mechanism that drives elemental fractionation away from parent rock signatures (Nesbitt \& Young 1982). The CIA value of the greywacke of the Hazara Formation is varying from 74 to 81 . These values propose that the source region of the sedimentary sequence were exposed to intense chemical weathering. The sediments were eroded and deposited under the climatic regime having a substantial rainfall.
It is leading interpretation that the rocks of the sequence are affected by resilient chemical weathering and formed under humid and warm climatic conditions. To further validate the paleoclimatic condition of Hazara Formation during the deposition, the binary plot of $\mathrm{Sr} / \mathrm{Cu}$ versus $\mathrm{Ga} /$ $\mathrm{Rb}$ has been used. Majority of the samples plotted in the humid-arid threshold area exception one sample fall in the warm-humid field (Figure 8). 


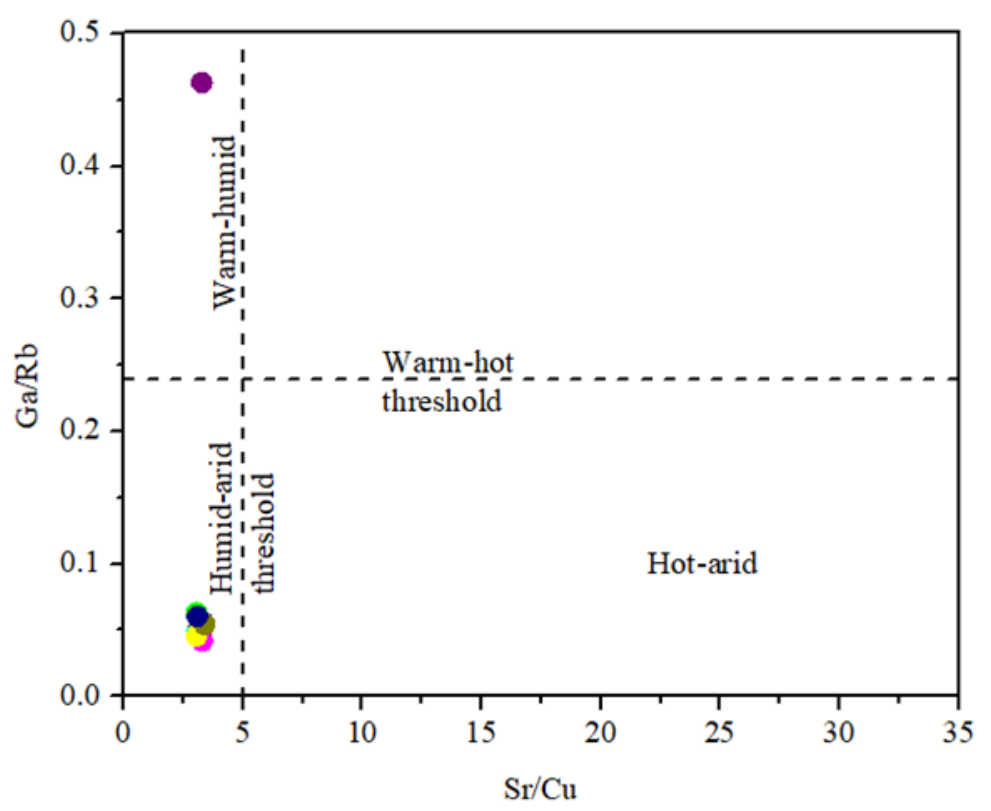

FIGURE 8. Cross plot of $\mathrm{Sr} / \mathrm{Cu}$ vs. Ga/Rb (Roy \& Roser 2012)

\section{PROVENANCE AND TECTONIC SETTINGS}

Based on the discrimination function diagram of major elements of Roser and Korsch (1988), all the investigated samples of greywacke were plotted in the felsic igneous provenance (Figure 10(b) \& 10(c)); this suggests that the greywacke originates from felsic igneous rocks. The major and trace element composition of the clastic sediments have been broadly used to understand the tectonic settings of the sedimentary basins (Bhatia $\&$ Crook 1986). The petrographic investigation of the sandstone provide information about the tectonic settings of the sedimentary basin, related provenance, and depositional settings (Dickinson et al. 1983). Greywacke composition shows the tectonics of the source area and also reflects the paleoclimatic conditions of the source area (Taylor \& McLennan 1985). The petrographic data of greywacke of the Hazara Formation is plotted on the QFL ternary diagram of the Dickinson (1985) for basin a terrain analysis the samples fall in the recycled orogenic (Figure 9), which discloses that the greywacke was derived from an exposed shield area or an area in a stable platform along an active continental margin tectonic setting (Dickinson 1985). The dominant quartz ratio shows that the sediments was transported from a low relief craton interior and experienced sustained transport (Dickinson 1979). The dominance of the monocrystalline quartz analysed samples of the greywacke proposed that the detritus were derived from granitic source rock (Basu 1975). Based on the Qt-F-L diagram plot (Figure
9), the detritus components mode of the greywacke falls into continental block provenance. Possibly the central Indian Craton, Aravalli orogeny, and Bundelkhand Craton, and Dharwar Craton. Whereas the Qm-f-L diagram of petrographic data fall in the continental block provenance with stable craton and uplifted basement source. The $\mathrm{K}_{2} \mathrm{O}$ / $\mathrm{Na}_{2} \mathrm{O}$ versus $\mathrm{SiO}_{2}$ diagram (Roser \& Korsch 1986) for the analyzed greywacke falls in the field of active continental margin tectonic settings (Figure 11). Immovable trace elements $\mathrm{Ce}, \mathrm{Nd}, \mathrm{Y}, \mathrm{La}, \mathrm{Zr}, \mathrm{Hf}, \mathrm{Nb}, \mathrm{Sc}$, and Ti, are used to classify the tectonic settings, which is affected by provenance, weathering, relief, sorting of sediments and post-depositional diagenesis (Bhatia 1983).

The petrographic analysis and geochemical analysis of the greywacke unit of the Hazara Formation suggests that the turbidite basin of the sequence was sourced by felsic rocks (Table 3). The provenance based on major elements concentration discriminant function diagram of Roser and Korsch (1986) is generally used by geoscientists to find the provenance of clastic rocks. The $\mathrm{K}_{2} \mathrm{O} / \mathrm{Na}_{2} \mathrm{O}$ versus $\mathrm{SiO}_{2}$ diagram after Roser and Korsch (1986) (Figure 8) for the analyzed greywacke samples plot in the field of active continental margin tectonic settings. The discrimination function diagram discloses the source of the detritus from a felsic source area. The geochemical differences between the elements like Th and La showing felsic source Sc is indicative of mafic source have been used in this study to discriminate between felsic and mafic provenance (Taylor \& McLennan 1985). The Ti/Zr versus 
$\mathrm{La} / \mathrm{Sc}$ and Co-Th-Zr (Figure 11(b) \& 11(c)) are very useful indicators of tectonic settings of the clastic sedimentary rocks (Bhatia \& Crooks 1986). All the examined samples fall in the active continental margin in the tectonic settings discrimination diagrams of $\mathrm{Ti} / \mathrm{Zr}$ versus $\mathrm{La} / \mathrm{Sc}$ and Co- Th- Zr (Figure 11(b) \& 11(c)).

TABLE 3. Modal composition of greywacke unit of the Hazara

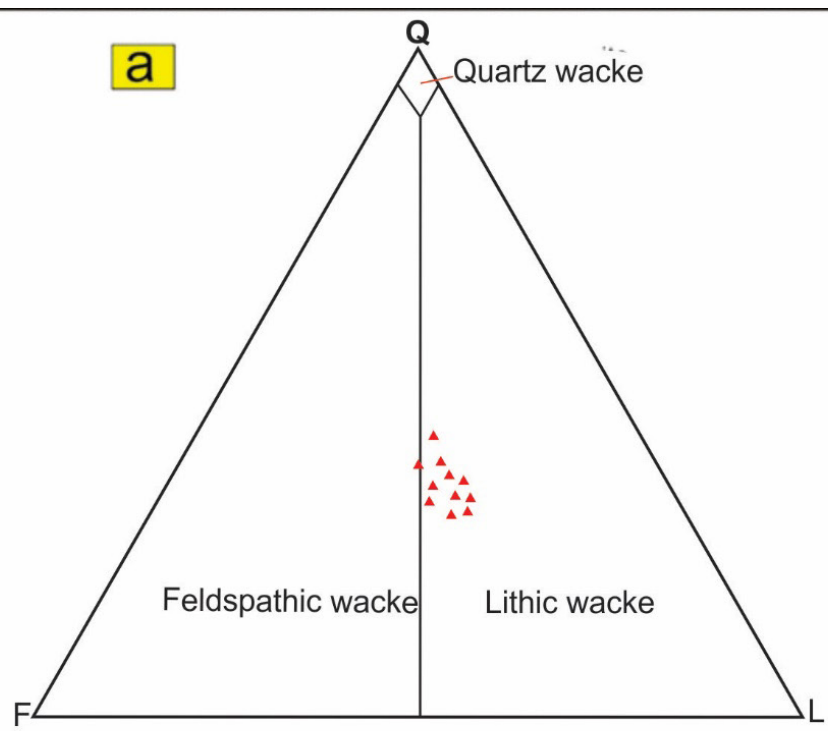

b

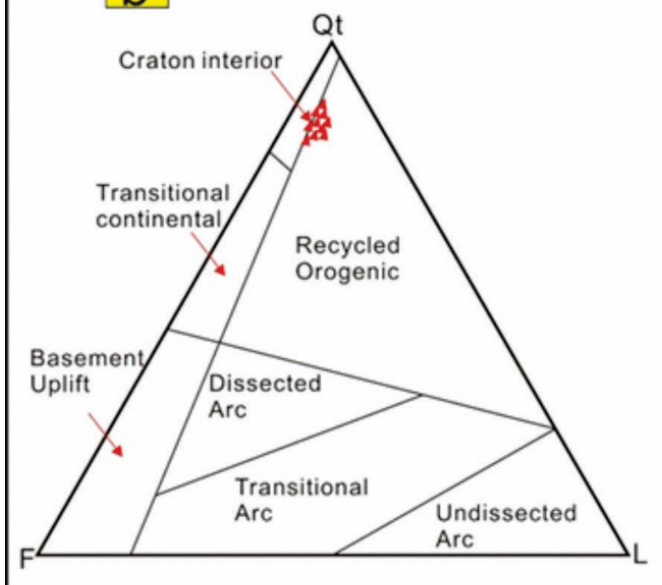

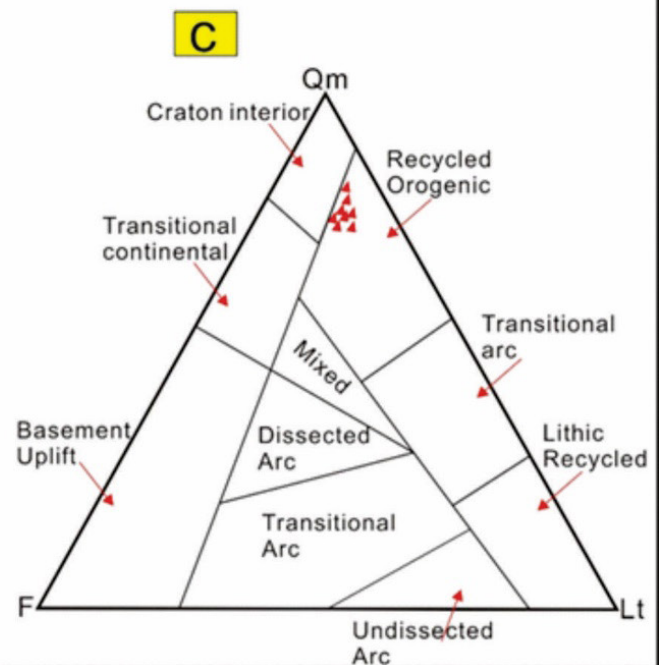

Arc

FIGURE 9. Model ternary plot for Greywacke of the Hazara Formation (a) showing the classification of the greywacke after Dott (1964), (b) QtFL, and (c) QmFLt ternary diagrams for the greywacke of the Hazara Formation after (Dickinson 1985) $F=$ feldspar, $L=$ rock fragments, $\mathrm{Qm}=$ quartz monocrystalline grains, $\mathrm{Qt}=$ total quartz, $\mathrm{Lt}=$ total lithic fragments 

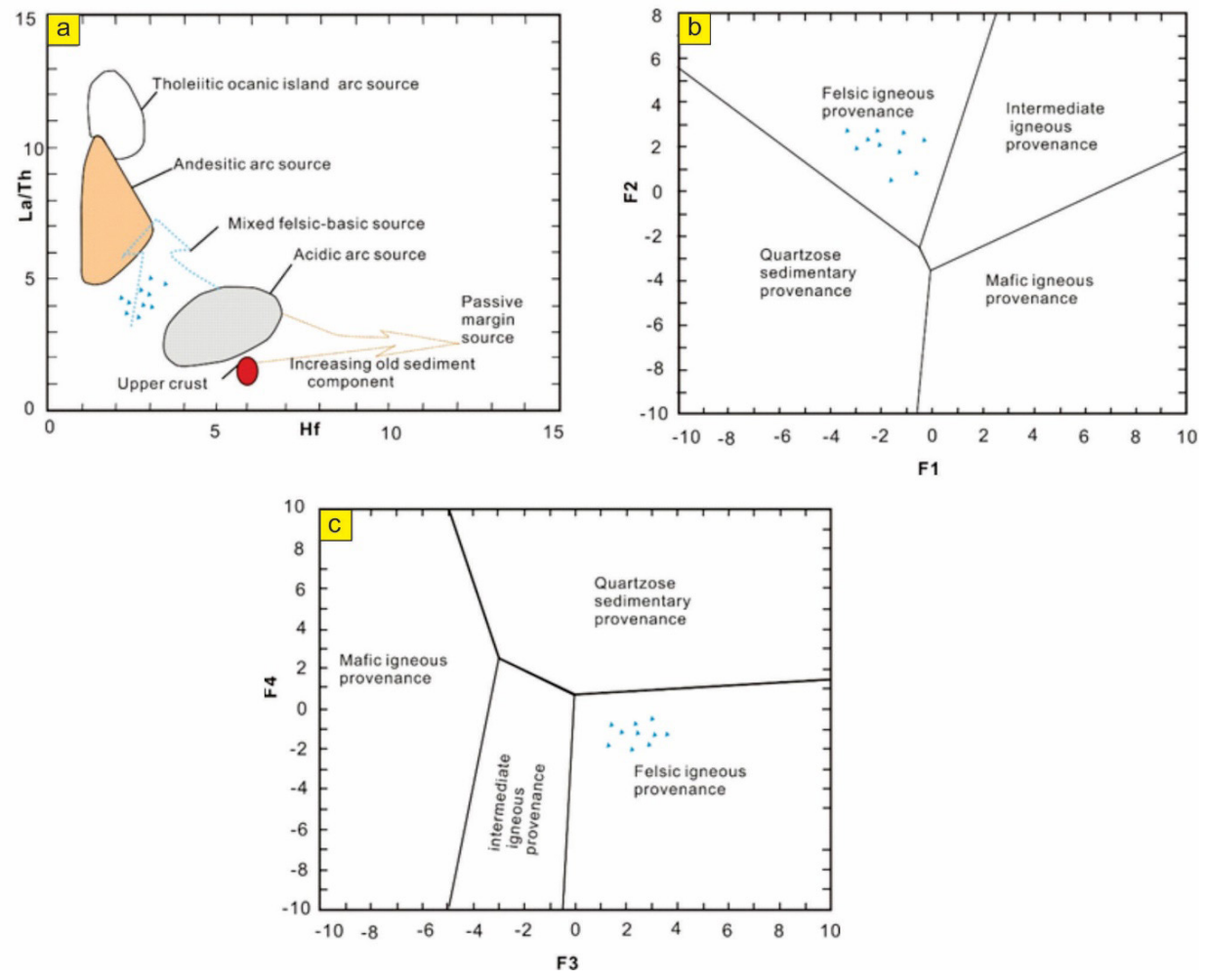

FIGURE 10. Tectonic setting discrimination diagrams for greywacke member of the Hazara Formation (a) $\mathrm{K}_{2} \mathrm{O} / \mathrm{Na}_{2} \mathrm{O}$ versus $\mathrm{SiO}_{2}$ of Roser and Korsch (1986), b) La/Th-Hf diagram (Floyd \& Leveridge 1987) indicating a felsic source and mixed felsic- basic source. (C,d) Provenance discrimination diagrams for major elements oxides composition of greywacke of the Hazara

Formation after (Roser \& Korsch 1988) reflecting felsic igneous provenance source
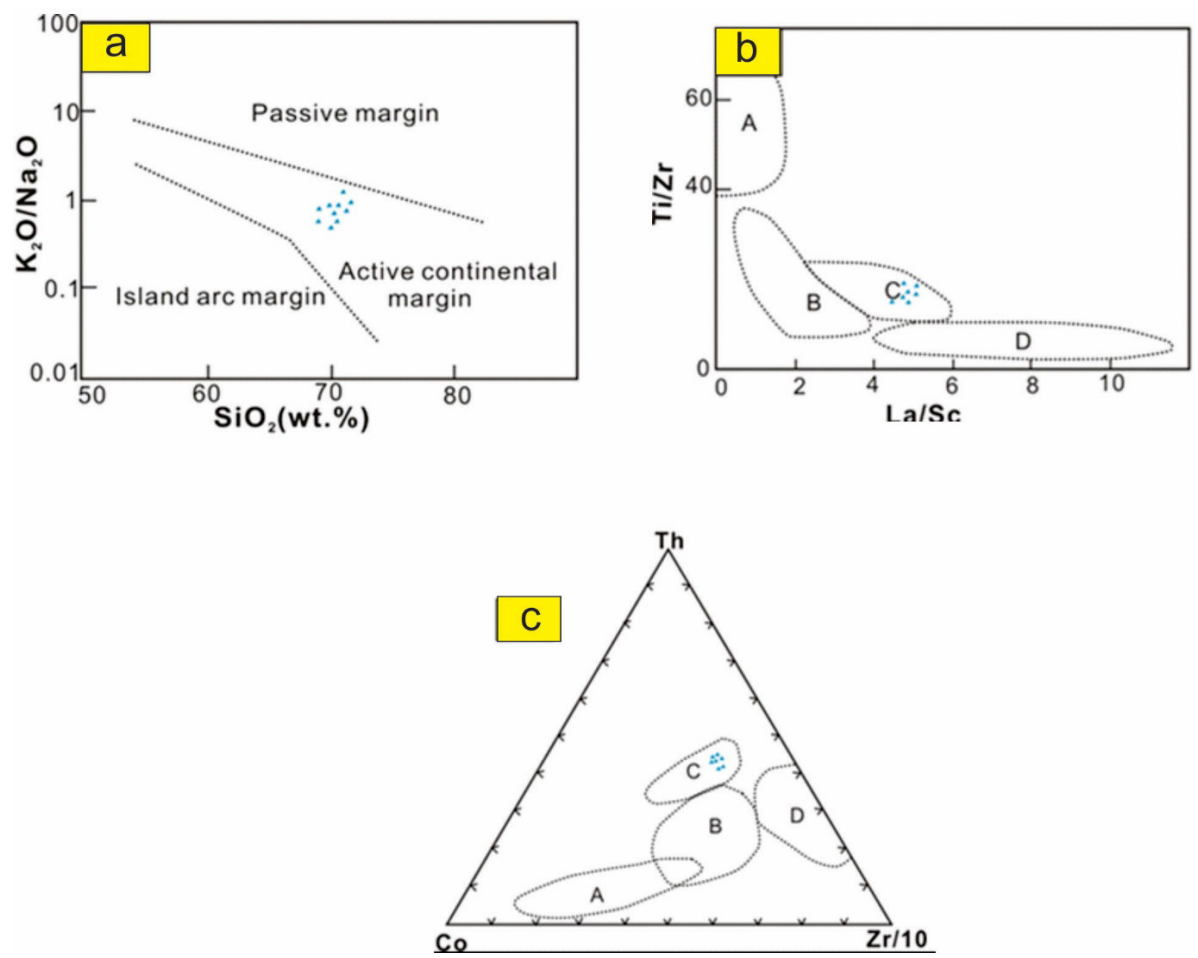

FIGURE 11. Tectonic setting discrimination diagrams for greywacke member of the Hazara Formation, (a) $\mathrm{K}_{2} \mathrm{O} / \mathrm{Na}_{2} \mathrm{O}$ versus $\mathrm{SiO}_{2}$ of Roser and Korsch (1986), (b) Ti/Zr against $\mathrm{La} / \mathrm{Sc}$ and (c) Co-Th-Zr ternary diagram of Bhatia and Crook (1986). A-Oceanic Island Arc; B-Continental Island Arc; C-Active Continental Margin; D-Passive Continental Margin 
Formation

\begin{tabular}{lccccccccc}
\hline Sample & Qt & F & L & Qm & Qp & P & K & Lt & M \\
\hline SS1 & 65 & 10 & 16.5 & 50 & 11 & 6 & 2 & 26 & 4 \\
SS2 & 70 & 8 & 15.2 & 49 & 11 & 4 & 2 & 28 & 2 \\
SS3 & 70 & 7 & 18 & 46 & 9 & 4 & 0.5 & 30 & 4 \\
SS4 & 63 & 9 & 19 & 48 & 9 & 5 & 2 & 25 & 1 \\
SS5 & 60 & 11 & 17 & 45 & 10 & 7 & 1 & 23 & 5 \\
SS6 & 64 & 9 & 21 & 52 & 12 & 8 & 2 & 19 & 5 \\
SS7 & 69 & 10 & 23 & 45 & 11 & 6 & 1 & 18 & 7 \\
SS8 & 69 & 8 & 22 & 50 & 11 & 6 & 1 & 28 & 4 \\
SS9 & 68 & 7 & 18 & 49 & 9 & 7 & 1 & 26 & 3 \\
SS10 & 70 & 10 & 25 & 46 & 10 & 4 & 0.5 & 27 & 2 \\
SS11 & 63 & 9 & 16 & 44 & 11 & 8 & 2 & 27 & 3 \\
SS12 & 65 & 8 & 18 & 42 & 10 & 7 & 1 & 29 & 1 \\
SS13 & 63 & 9 & 17 & 46 & 12 & 7 & 2 & 24 & 5 \\
SS14 & 62 & 10 & 15 & 46 & 8 & 6 & 2 & 28 & 1 \\
SS15 & 60 & 8 & 21 & 50 & 9 & 5 & 1 & 19 & 3 \\
\hline
\end{tabular}

$\mathrm{Qt}=$ quartz total; $\mathrm{F}=$ Felsapar; $\mathrm{L}=$ lithic fragments; $\mathrm{Qm}=$ monocrystalline quartz; $\mathrm{Qp}=$ polycrystalline quartz, $\mathrm{P}=$ plagioclase feldspar; $\mathrm{K}=\mathrm{Potassium}$ feldspar; $\mathrm{Lt}=\mathrm{total}$ lithic fragments, and $\mathrm{M}=$ mica

\section{CONCLUSION}

The petrographic and geochemical analysis of the greywacke of the late Neoproterozoic Hazara were carried out to conclude the provenance, source area weathering and tectonic settings in which the sequence was deposited. The geochemical characteristics of greywacke deliver considerable information about the tectonic setting, provenance and nature of source rocks. The provenance and tectonic settings of the greywacke of the Hazara Formation are represented by the felsic igneous provenance. The original source rocks were all derived from the mixed felsic, with felsic rocks dominant. The sedimentary structure such as graded bedding is typical feature of turbidites deposits formed by gravitational deposition of sediments from turbidity flows in deep marine depositional environment. The petrographic analysis shows presence of quartz, feldspar and rock fragments and suggests a felsic source provenance for the greywacke. The CIA, CIW, PIA, CIA and A-CN- K plot values of the analysed samples shows that the source area has experienced severe chemical weathering. The $\mathrm{Th} / \mathrm{Sc}, \mathrm{Co} / \mathrm{Th}, \mathrm{La} / \mathrm{Sc} \mathrm{Cr} / \mathrm{Th}$ values suggest that a significant input of detrital material of the felsic composition. The sedimentary-tectonic model based on major element data of greywacke suggests deposition along active continental margin tectonic settings.

\section{ACKNOWLEDGEMENTS}

The first author is thankful to the Department of Geology, Northwest University Xian for permission to use Laboratories for this work. Funding for this work was provided by the Natural Science Foundation of China grant (No: 41390451). We are grateful to the administration of the School of International Cultural Exchange and the Department of Geology Northwest University for allowing us to undertake this research. Qamar UZ Zaman Dar (Ph.D. Candidate) contributed substantially to the conception and design of this study, the data collection, data analysis and interpretation. $\mathrm{Pu}$ Renhai (Professor) drafted and provided critical revision of this article. Zulqarnain Sajid (PhD. Candidate): provided lithofacies and Petrographic analysis. Mubashir Mehmood (PhD. Candidate) participated in statistical analysis and log interpretation. Muhammad Jehangir Khan (Research Assistant) provided the analysis and interpretations of geochemical data. Abdul Wahab (PhD. Candidate) worked out on the geological setting of the area. Tajammal 
Latif Janjua ( $\mathrm{PhD}$. Candidate) performed the field work, contributing with the geology of the Hazara Area.

\section{REFERENCES}

Absar, N., Raza, M., Roy, M., Naqvi, S. \& Roy, A.K. 2009. Composition and weathering conditions of Paleoproterozoic upper crust of Bundelkhand craton, Central India: Records from geochemistry of clastic sediments of $1.9 \mathrm{Ga}$ Gwalior Group. Precambrian Research 168(3-4): 313-329.

As-Saruri, M.A., Rasoul, S. \& Baraba, R. 2010. Sedimentary basins of Yemen: Their tectonic development and lithostratigraphic cover. Arab J. Geosci. 3: 515-527.

Basu, A. 1985. Reading provenance from Detrital Quartz. In Provenance of Arenites, edited by Zuffa, G.G. Dordrecht: Springer. pp. 231-247.

Basu, A., Young, S.W., Suttner, L.J., James, W.C. \& Mack, G.H. 1975. Re-evaluation of the use of undulatory extinction and polycrystallinity in detrital quartz for provenance interpretation. J. Sediment. Res. 45(4): 873-882.

Bau, M. \& Dulski, P. 1996. Anthropogenic origin of positive gadolinium anomalies in river waters. Earth and Planetary Science Letters 143: 245-255. http://dx.doi.org/10.1016/0012-821X(96)00127-6.

Bhatia, M.R. 1983. Plate tectonics and geochemical composition of sandstones. The Journal of Geology 91(6): 611-627.

Bhatia, M.R. \& Crook, K.A. 1986. Trace element characteristics of graywackes and tectonic setting discrimination of sedimentary basins. Contributions to Mineralogy and Petrology 92: 181-193.

Bossart, P., Dietrich, D., Greco, A., Ottiger, R. \& Ramsay, J.G. 1988. The tectonic structure of the Hazara-Kashmir syntaxis, southern Himalayas, Pakistan. Tectonics 7(2): 273-297.

Butt, A.A. 1972. Problems of stratigraphic nomenclature in the Hazara District, NWFP, Pakistan. Geological Bulletin of Punjab University 9: 65-69.

Cullers, R.L. 1994. The controls on the major and trace element variation of shales, siltstones, and sandstones of Pennsylvanian-Permian age from uplifted continental blocks in Colorado to platform sediment in Kansas, USA. Geochimica et Cosmochimica Acta 58(22): 4955-4972.

Cox, R., Lowe, D.R. \& Cullers, R.L. 1995. The influence of sediment recycling and basement composition on evolution of mudrock chemistry in the southwestern United States. Geochim Cosmochim Acta 59(14): 2919-2940.

Dai, S., Graham, I. \& Ward, C.R. 2016. A review of anomalous rare earth elements and yttrium in coal. International Journal of Coal Geology 159: 82-95. https://doi.org/10.1016/j. coal.2016.04.005.

Dar, Q.U.Z., Renhai, P., Ghazi, S., Sajid, Z., Wahab, A., Zubair, R.A. \& Aziz, T. 2021. The Precambrian Hazara Formation from Hazara Mountains, Northern Pakistan. Arab J. Geosci. 14: 134. https://doi.org/10.1007/s12517-021-06496-7.

Dickinson, W.R. 1985. Interpreting provenance relations from detrital modes of sandstones. In Provenance of Arenites, edited by Zuffa, G.G. Dordrecht: Springer. pp. 333-361.
Dickinson, W.R. \& Suczek, C.A. 1979. Plate tectonics and sandstone compositions. AAPG Bulletin 63(12): 2164-2182.

Dickinson, W.R., Beard, L.S., Brakenridge, G.R., Erjavec, J.L., Ferguson, R.C., Inman, K.F., Knepp, R.A., Lindberg, F.A. \& Ryberg, P.T. 1983. Provenance of North American Phanerozoic sandstones in relation to tectonic setting. Geological Society of America Bulletin 94(2): 222235.

Fedo, C.M., Nesbitt, H.W. \& Young, G.M. 1995. Unraveling the effects of potassium metasomatism in sedimentary rocks and paleosols, with implications for paleoweathering conditions and provenance. Geology 23(10): 921-924.

Greco, A., Martinotti, G., Papritz, K., Ramsay, J.G. \& Rey, R. 1989. The crystalline rocks of the Kaghan Valley (NEPakistan). Eclogae Geologicae Helvetiae 82(2): 629-653.

Herron, M.M. 1988. Geochemical classification of terrigenous sands and shales from core or log data. Journal of Sedimentary Research 58(5): 820-829.

Holland, H.D. 1978. The Chemistry of the Atmosphere and Oceans. New York: John Wiley \& Sons Inc.

Hylland, M.D. 1990. Geology of the southern Gandghar range and Kherimar hills, Northern Pakistan. Oregon State University, M.Sc. Thesis (Unpublished).

Marks, P. \& Ali, C.M. 1961. The geology of the Abbottabad area, with special reference to the Infra-Trias. Geological Bulletin of Punjab University 1: 47-56.

Marston, R.J. 1978. The geochemistry of the archaean clastic metasediments in relation to crustal evolution, northeastern Yilgarn Block, Western Australia. Precambrian Research 6(2): 157-175.

McLennan, S., Hemming, S., McDaniel, D. \& Hanson, G. 1993. Geochemical approaches to sedimentation, provenance, and tectonics. In Processes Controlling the Composition of Clastic Sediments, edited by Johnsson, M.J. \& Basu, A. Colorado: Geological Society of America. pp. 21-40.

Middlemiss, C.S. 1896. The Geology of Hazara and the Black Mountain. London: Geological Survey. pp. 302.

Nesbitt, H.W. \& Young, G.M. 1996. Petrogenesis of sediments in the absence of chemical weathering: Effects of abrasion and sorting on bulk composition and mineralogy. Sedimentology 43(2): 341-358.

Nesbitt, H. \& Young, G. 1984. Prediction of some weathering trends of plutonic and volcanic rocks based on thermodynamic and kinetic considerations. Geochimica et Cosmochimica Acta 48(7): 1523-1534.

Nesbitt, H.W. \& Young, G. 1982. Early Proterozoic climates and plate motions inferred from major element chemistry of lutites. Nature 299: 715-717.

Pettijohn, F.J., Potter, P.E. \& Siever, R. 1972. Sand and Sandstone. New York: Springer Science \& Business Media.

Pettijohn, F.J., Potter, P.E. \& Siever, R. 1987. Sand and Sandstone. 2nd ed. New York: Springer Science \& Business Media. pp. 148-290.

Qasim, M., Ding, L., Khan, M.A., Umar, M., Jadoon, I.A., Haneef, M., Baral, U., Cai, F., Shah, A. \& Yao, W. 2018. Late Neoproterozoic-Early Palaeozoic stratigraphic 
succession, Western Himalaya, North Pakistan: Detrital zircon provenance and tectonic implications. Geological Journal 53(5): 2258-2279.

Roser, B.P. \& Korsch, R.J. 1986. Determination of tectonic setting of sandstone-mudstone suites using $\mathrm{SiO}_{2}$ content and $\mathrm{K}_{2} \mathrm{O}$ / $\mathrm{Na}_{2} \mathrm{O}$ ratio. The Journal of Geology 94(5): 635-650.

Roser, B. \& Korsch, R. 1988. Provenance signatures of sandstone-mudstone suites determined using discriminant function analysis of major-element data. Chemical Geology 67(1-2): 119-139.

Seeber, L., Armbruster, J.G. \& Quittmeyer, R.C. 1981. Seismicity and continental subduction in the Himalayan arc. In Zagros Hindukush Himalaya, Geodynamic Evolution, edited by Gupta, H.K. \& Delany, F.M. Washington DC: American Geophysical Union. pp. 215-242.

Shah, M.T. \& Moon, C.J. 2004. Mineralogy, geochemistry and genesis of the ferromanganese ores from Hazara area NW Himalayas northern Pakistan. J. Asian Earth Sci. 23: 1-15.

Tahirkheli, R.K. 1979. Geology of Kohistan and adjoining Eurasian and Indo-Pakistan continents, Pakistan. Geological Bulletin (University of Peshawar) 11(1): 1-30.

Taylor, S.R. 1985. An examination of the geochemical record preserved in sedimentary rocks, In The Continental Crust: Its Composition and Evolution, edited by Taylor, S.R. \& McLennan, S.M. Oxford: Blackwell Scientific Publications. p. 312 .

Umar, M., Betts, P., Khan, M.M.S., Sabir, M.A., Farooq, M., Zeb, A., Jadoon, U.K. \& Ali, S. 2015. Signatures of late Neoproterozoic Gondwana assembly and Maronian glaciation in Lesser Himalaya: A palaeogeographical and stratigraphical approach. Acta Geologica Polonica 65(1): $1-19$.

Wadia, D. 1931. The syntaxis of the northwest Himalaya: Its rocks, tectonics and orogeny. Geological Survey of India 65(2): 189-220.

Wang, D., Wang, X.L., Zhou, J.C. \& Shu, X.J. 2013. Unraveling the Precambrian crustal evolution by Neoproterozoic conglomerates, Jiangnan orogen: $\mathrm{U}-\mathrm{Pb}$ and $\mathrm{Hf}$ isotopes of detrital zircons. Precambrian Research 233: 223-236.

Wimmenauer, W, 1984. Das pravariskische Kristallin im Schwarzwald. Fortschritt der Mineralogie 62: 69-86.
Wynne, A.B. 1878. On the geology of the Salt Range in the Punjab. Geological Survey of India 14: 98.

Yeats, R.S. \& Hussain, A. 1987. Timing of structural events in the Himalayan foothills of northwestern Pakistan. Geological Society of America Bulletin 99(2): 161-176.

Zeitler, P.K. 1985. Cooling history of the NW Himalaya, Pakistan. Techtonics 4(1): 127-151.

Qamar UZ Zaman Dar \& Pu Renhai*

Department of Geology

Northwest University

710069, Xi'an

People Republic of China

Zulqarnain Sajid

Geosciences Department

Universiti Teknologi PETRONAS

32610 Bandar Seri Iskandar, Perak Darul Ridzuan

Malaysia

Mubashir Mehmood

Department of Geology

Abdul Wali Khan University

23130, Mardan

Pakistan

Abdul Wahab

College of Engineering Universiti Malaysia Pahang

Lebuhraya Tun Razak

26300 Gambang, Kuantan, Pahang Darul Makmur Malaysia

Muhammad Jehangir Khan \& Tajjamal Latif

Institute of Geology

University of the Punjab

54000, Lahore

Pakistan

*Corresponding author; email: 552418459@qq.com

Received: 4 November 2020

Accepted: 31 March 2021 